\title{
Perkutánní katetrizační uzávěr persistujícího ductus arteriosus Botalli pomocí Amplatzova okluderu u staršího pacienta
}

\section{POPIS PR̆ÍPADU}

Nechirurgický uzávěr ductus arteriosus je metodou volby v léčbě této

vrozené srdeční vady v dospělosti.

Nejvíce zkušeností je v současné době

s uzávěry pomocí Amplatzova okluderu.

V kasuistickém sdělení prezentujeme

případ 70leté pacientky, diabetičky,

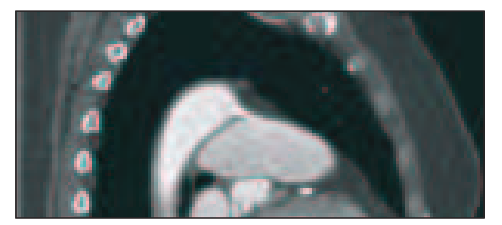

Obr. 1 CT angiografie s použitím EKG gating, před implantací

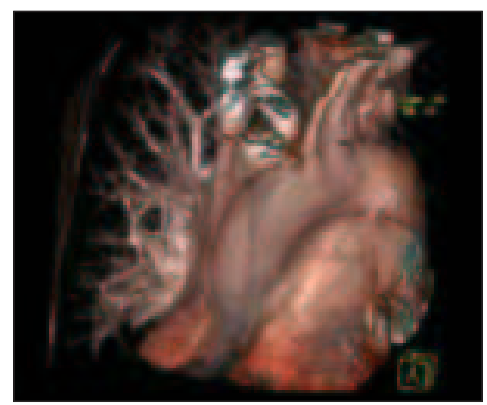

Obr. 2 Rekonstrukce vyšetření CT se zaměřením na levo-pravý zkrat, ductus arteriosus a jeho morfologii

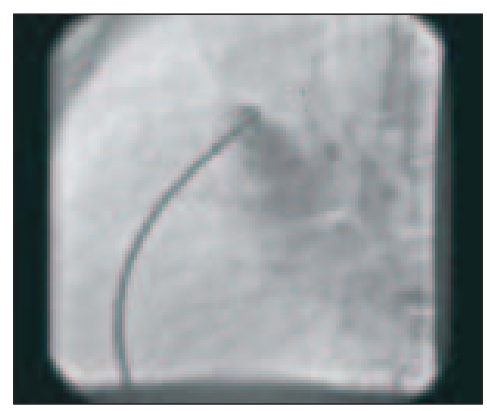

Obr. 3 Implantace Amplatzova okluderu; $\mathrm{z}$ pravostranních oddílů zaveden katetr $\mathrm{s}$ okluderem a následně rozvinutí okluderu přesně do ductus arteriosus; kontrastní ru presně do ductus arteriosus; kontrast
látkou byl potvrzen kompletní uzávěr hypertoničky po prodělané cévn mozkové příhodě v anamnéze, která byla na našem pracovišti vyšetřena pro progredující námahovou dušnost a stenokardie. Transtorakální a následně i jícnové echokardiografické vyšetření prokázalo lehkou plicní arteriální hypertenzi a turbulentní tok

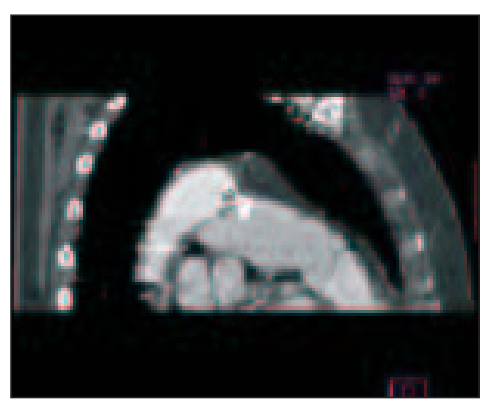

Obr. 4 CT angiografie s použitím EKG gating, po implantaci

do arterie pulmonalis se suspekcí na persistující ductus arteriosus. Nebyla zjištěna dilatace srdečních oddílů ani porucha kinetiky levé komory srdeční s normálnî systolickou funkcí. Aortální chlopeň trojcípá bez vady. Nemocná podstoupila oboustrannou srdeční katetrizaci. Selektivní koronarografie vyloučila významné stenózy na věnčitém řečišti.

Angiograficky i dilučně byl potvrzen ductus arteriosus s velikostí zkratu Qp/Qs 1,5 a potvrzena mírná prekapilární plicní arteriální hypertenze. Diagnostika byla doplněna o CT angiografii a EKG gating, jež také jednoznačně prokázala persistující ductus na straně aorty za odstupem levé podkličkové arterie do místa bifurkace arteria pulmonalis, délky $10 \mathrm{~mm}$ a šíře $3,5 \mathrm{~mm}$.

Defekt byl následně uzavřen pomocí Amplatzova okluderu velikosti 12/10 mm cestou pravé stehenní žíly za použití $8 \mathrm{~F}$ instrumentária. Ductus byl sondován retrográdně $z$ aorty se zavedením vodícího drátu do pravé srdeční komory a jeho vytažením kličkou přes pravou stehenní žílu. Poté po vytaženém zaváděcím drátu byl zaveden katetr, přes který jsme implantovali okluder.

Angiografie prokazovala dobrou polohu okluderu. Po uvolnění zaváděcího kabelu okluder obturoval původní ductus arteriosus. Finální angiografie plicnice i aortografie

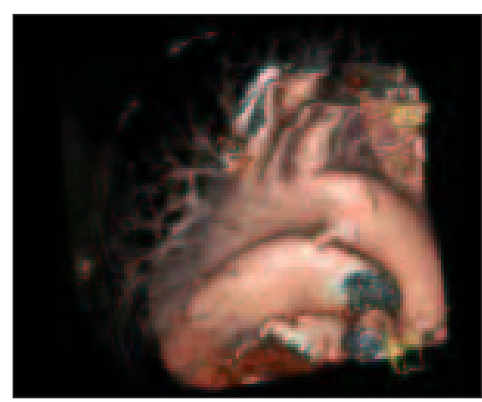

Obr. 5 Rekonstrukce vyšetření CT se zaměřením na okluder, umístěn ve zkratu

prokázala kompletní uzávěr zkratu přes ductus arteriosus. Kontrolní CT angiografie a EKG gating zobrazily optimální pozici okluderu.

Výkon i hospitalizace proběhly bez komplikací. V další terapii byla doporučena 6 měsíční antiagregace aspirinem, kombinační antihypertenzní terapie (inhibitor ACE a betablokátor) a doporučení prevence bakteriální endokarditidy.

\section{ZÁVĚR}

Kasuistika dokumentuje úspěšný nekomplikovaný nechirurgický uzávěr persistujícího ductus arteriosus pomocí Amplatzova okluderu s využitím interdisciplinárního přistupu $\mathrm{v}$ diagnostice a léčby této $\mathrm{v}$ dospělosti nepř́liš časté vrozené vady.

\section{LITERATURA}

1. Štejfa M a spol. Kardiologie. 3. vydání Praha: Grada publishing, 2007:658.

2. Braunwald E, at al. Braunwald's Heart Disease. 7th ed. New York: Elsevier Saunders, 2005:1511-3.

Jozef Jakabčin, Pavel Červinka, Marian Bystroň, Josef Dražka, Petr Sternthal*, Milouš Derner**

Kardiologické oddělení, Masarykova nemocnice Ústí nad Labem, Ústí nad Labem, *Interní oddělení, Nemocnice Teplice, Teplice, **Radiologické oddělení, Masarykova nemocnice Ústí nad Labem, Ústí nad Labem, Česká republika

Adresa: MUDr. Jozef Jakabčin, Kardiologické oddělení, Masarykova nemocnice Ústí nad Labem, Sociální péče $12 A$, 413 01 Ústî nad Labem, Česká republika, e-mail: jozef.jakabcin@mnul.cz 